\title{
The Effect Of Guided Inquiry Learning Model on Student's Science Process Skills and Cognitive Ability About Water Cycle in Elementary School
}

\author{
Rizqi Yusriana \\ Post Graduate School \\ State University of Medan \\ Medan, Indonesia \\ Rizqiyusriana91@gmail.com
}

\author{
Nurdin Bukit \\ Post Graduate School \\ State University of Medan \\ Medan, Indonesia \\ Nurdinbukit5@gmail.com
}

\author{
Ely Djulia \\ Post Graduate School \\ State University of Medan \\ Medan, Indonesia \\ Djulia247@gmail.com
}

\begin{abstract}
The science learning process emphasizes giving direct experience to students. Science consists of three elements, namely products, processes, and attitudes. In learning science, requires science process skills, which involve mental and cognitive processes so that the knowledge gained by students is meaningful. This study aims to analyze the effect of guided inquiry learning models on science process skills and cognitive abilities of elementary students. This study was a quasiexperimental study with two group pretest-posttest designs. The population of this study was all fifth-grade students of SD Negeri 106205 Pasar Baru that consisting of two classes. Performed in the second semester of the $2018 / 2019$. The sample selection uses total sampling technique. The instrument of this study was a science process skill test and cognitive ability tests in the form of multiple choice tests each consisting of 20 questions which were declared valid by the expert team. The data were analyzed using a t-test with a significance level 0.05 . The results showed the average value of science process skills guided inquiry class of 75.71 and conventional classes of 64.28. The average value of cognitive abilities of the guided inquiry class is $\mathbf{7 6 . 4 2}$ and the conventional class is 65.17 . The conclusion is that science process skills and cognitive abilities of students taught with guided inquiry learning models are better than science process skills and cognitive abilities of students who are taught with conventional learning.
\end{abstract}

Keywords- Guided Inquiry Learning; Science Process Skills; Cognitive Ability

\section{INTRODUCTION}

Based on observations made at SDN 106205 Pasar Baru, science learning designed by teachers is still not able to develop student competencies to be able to understand the natural surroundings. Not yet practicing science process skills, the ability to think, work, and be scientific and the ability to communicate the results of learning.

Science learning emphasizes giving direct experience to students to develop their competencies to be able to understand the natural environment. With the learning process of science it is expected to develop process skills, understanding concepts and their application in the daily lives of students.
Susanto (2014: 167) argues that science is a human effort in understanding the universe through observing the right on the target, and using procedures, and explained by reasoning to get a conclusion. Science can be classified into three parts, namely as a product, process and attitude, and to understand science requires skills called Science Process Skills (KPS). KPS is a skill carried out by scientists, such as observing, measuring, classifying, and inferring.

In learning, students need to be guided to find concepts of science themselves. Students are expected to be actively involved through observing, asking questions, collecting data, analyzing data, and communicating their findings.

Based on observations made at SDN 106205 Pasar Baru, science learning designed by teachers is still not able to develop student competencies to be able to understand the natural surroundings. Also still not practicing science process skills, the ability to think, work, and be scientific and the ability to communicate the results of learning.

When science learning the teacher becomes the main source of information. The teacher does not design a learning activity that makes active students to find out for themselves the concepts of knowledge. Even though if students find their own knowledge concepts in the learning process, the knowledge gained by students will be very meaningful. Less attractive learning makes students less responsive and attentive to learning activities. This causes the student learning outcomes in the cognitive realm are low.

Then the teacher needs to design learning using the right learning model. Learning that prioritizes student involvement in building knowledge can be carried out using inquiry learning models. Sanjaya (2014: 196) argues that "Inquiry learning model is a series of learning activities that emphasize the process of thinking critically and analytically to find and find answers to a question that is questioned".

Based on the explanation above, the writer feels the need to conduct a study to find out the Effect of Guided Inquiry Learning Model on Science Process Skills and Student Cognitive Abilities About the Water Cycle in Elementary Schools. 
Guided inquiry learning models can train students to develop scientific attitudes and improve their ability to find concepts. Through a guided inquiry learning model the teacher acts as a guide for students in conducting experiments and discovering concepts by providing direction and guidelines to carry out learning activities to students.

Researches on the use of Guided Inquiry learning models have been carried out previously. There are research of Metaputri, \& Garminah (2016), Susilawati, Susilawati, \& Nyoman (2015), Muliati \& Bukit (2016), Lubis, Djulia, \& Syahmi (2016), and Anam (2015) the results of these studies indicate that science process skills and cognitive abilities of students taught by guided inquiry learning are better than conventional learning.

\section{RESEARCH OBJECTIVES}

\section{A. The Purpose of the Study}

The purpose of this study was to determine the effect of guided inquiry learning models on science process skills and cognitive abilities of students.

\section{B. Research Questions}

- How does the guided and conventional inquiry learning influence the science process skills of students in the sub-themes of Humans and the Environment in class V SDN 106205 Pasar Baru?

- How does the guided inquiry learning model affect the cognitive abilities of students in the sub-themes of Humans and the Environment in class V SDN 106205 Pasar Baru?

\section{Research Hypothesis}

- Ho: Science process skills of students taught with guided inquiry learning models are lower or the same as science process skills students who are taught with conventional learning in the material of the water cycle of the Human and Environmental sub-themes in class V SDN 106205 Pasar Baru

- Ha: Science process skills of students taught with guided inquiry learning models are higher than science process skills students who are taught with conventional learning on the material of the water cycle of the Human and Environmental sub-themes in class V SDN 106205 Pasar Baru.

- Ho: Cognitive abilities of students taught with guided inquiry learning models are lower or equal to the cognitive abilities of students taught with conventional learning in the material of the water cycle of the Human and Environmental sub-themes in class V SDN 106205 Pasar Baru.

- Ha : The cognitive abilities of students taught with guided inquiry learning models are higher than the cognitive abilities of students taught with conventional learning in the material of the water cycle of the Human and Environmental sub-themes in class V SDN 106205 Pasar Baru.

\section{METHOD}

This study uses Two Group Pretest-Posttest Design. The research design is presented in TABLE I.

TABLE I. RESEARCH DESIGN

\begin{tabular}{cccc}
\hline Class & Pretest & Treatment & Posttest \\
\hline Experiment & $\mathrm{T}_{1}$ & $\mathrm{X}_{1}$ & $\mathrm{~T}_{2}$ \\
Control & $\mathrm{T}_{1}$ & $\mathrm{X}_{2}$ & $\mathrm{~T}_{2}$ \\
\hline
\end{tabular}

Explanation:

$\mathrm{X}$ : Guided Inquiry learning model

X2: Conventional Learning Models

T1: Pretest science process skills and cognitive abilities of students

T2: Posttest the science process skills and cognitive abilities of students after implementing the Guided and Conventional Inquiry learning model

Before being given treatment, students were given a pretest to find out whether the two classes had a normal distribution and a homogeneous variance. Next is a hypothesis test.

After carrying out the pretest both classes were treated. The VA class is taught with conventional learning and the VB class is taught with guided inquiry learning. After receiving treatment the two classes were given posttest.

To measure science process skills students used multiple choice tests totaling 20 questions representing KPS indicators, namely: observing, classifying, interpreting, predicting, communicating, making hypotheses, planning research, applying concepts and principles and asking questions.

To measure the cognitive abilities of students used multiple choice tests totaling 20 questions representing cognitive abilities (C1), understanding (C2), applying (C3), and analyzing $(\mathrm{C} 4)$.

\section{ANALYSIS OF DATA}

The data analysis technique in this study is descriptive and inferential statistics. Before testing the hypothesis, the prerequisite test for the data obtained first is to do a normality test using the Kolmogorov-Smirnov approach and homogeneity test using the Levene's Test approach.

After conducting the prerequisite test then the research hypothesis test is carried out with the t-test with a level of $\alpha=$ 0.05. Data processing is done using SPSS 16.0.

\section{RESULTS}

A summary of the research data is presented in the following table: 
TABLE II. PRETEST AND POST-TEST OF SCIENCE PROCESS SKILLS OF GRADE V ELEMENTARY SCHOOL STUDENTS ABOUT THE WATER CYCLE

\begin{tabular}{ccc}
\hline \multirow{2}{*}{ Learning Model } & \multicolumn{2}{c}{ Science Process Skills } \\
\cline { 2 - 3 } & Pretest & Posttest \\
\hline Guided Inquiry & 44,10 & 75,71 \\
\hline Conventional & 43,57 & 64,28 \\
\hline
\end{tabular}

TABLE III. TEST FOR THE NORMALITY OF SCIENCE PROCESS SKILLS GUIDED INQUIRY AND CONVENTIONAL CLASS STUDENTS

\begin{tabular}{cccc}
\hline & \multicolumn{2}{c}{ Shapiro-Wilk } & \\
\cline { 2 - 3 } Learning Model & \multicolumn{2}{c}{ Science Process } & Descrip \\
& \multicolumn{2}{c}{ Skills } & tion \\
\cline { 2 - 3 } & Pretest & $\begin{array}{c}\text { Posttes } \\
\mathbf{t}\end{array}$ & \\
\hline Guided Inquiry & 0,826 & 0,076 & Normal \\
\hline Conventional & 0,211 & 0,080 & \\
\hline
\end{tabular}

TABLE IV. TEST OF HOMOGENEITY OF SCIENCE PROCESS SKILLS GUIDED INQUIRY AND CONVENTIONAL CLASS STUDENTS

\begin{tabular}{ccc}
\hline \multirow{2}{*}{ Rated Aspect } & \multicolumn{2}{c}{ Levene Statistic } \\
\cline { 2 - 3 } & Pretest & Posttest \\
\hline Science Process Skills & 0,086 & 0,448 \\
\hline Description & Homogeneous \\
\hline
\end{tabular}

TABLE V. PRETEST AND POSTTEST OF COGNITIVE ABILITY OF GRADE V ELEMENTARY SCHOOL STUDENTS ABOUT THE WATER CYCLE

\begin{tabular}{ccc}
\hline \multirow{2}{*}{ Learning Model } & \multicolumn{2}{c}{ Cognitive Ability } \\
\cline { 2 - 3 } & Pretest & Posttest \\
\hline Guided Inquiry & 36,42 & 76,42 \\
\hline Conventional & 35,53 & 65,17 \\
\hline
\end{tabular}

TABLE VI. NORMALITY TEST OF COGNITIVE CAPABILITIES OF GUIDED INQUIRY AND CONVENTIONAL CLASS STUDENTS

\begin{tabular}{|c|c|c|c|}
\hline \multirow{3}{*}{ Learning Model } & \multicolumn{2}{|c|}{ Shapiro-Wilk } & \multirow{3}{*}{ Desc. } \\
\hline & \multicolumn{2}{|c|}{ Cognitive Ability } & \\
\hline & Pretest & Posttest & \\
\hline Guided Inquiry & 0,357 & 0,120 & \multirow{2}{*}{ Normal } \\
\hline Conventional & 0,226 & 0,078 & \\
\hline
\end{tabular}

TABLE VII. TEST OF HOMOGENEITY OF SCIENCE PROCESS SKILLS GUIDED INQUIRY AND CONVENTIONAL CLASS STUDENTS

\begin{tabular}{ccc}
\hline \multirow{2}{*}{ Rated Aspect } & \multicolumn{2}{c}{ Levene Statistic } \\
\cline { 2 - 3 } & Pretest & Posttest \\
\hline Cognitive Ability & 0,405 & 0,980 \\
\hline Description & \multicolumn{2}{c}{ Homogeneous } \\
\hline
\end{tabular}

A. Effects of Learning Models on Science Process Skills

The results of the t-test show that the guided inquiry learning model significantly influences students' science process skills. Science process skills of students taught with guided inquiry 75.71 were significantly higher than students' science process skills taught with conventional learning 64.28 (Fig. 1).

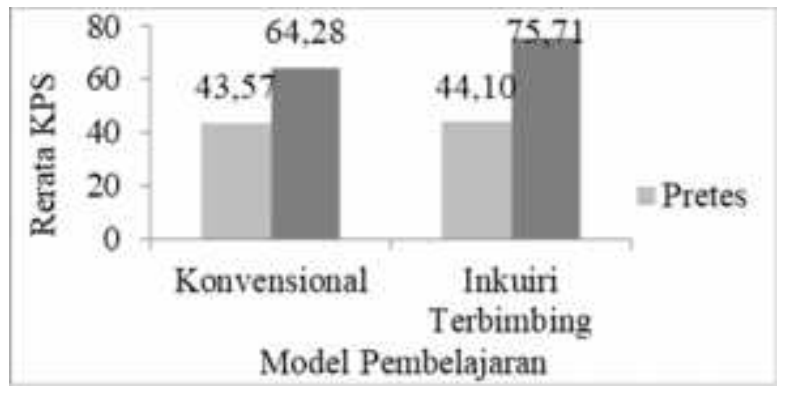

Fig. 1. Differences in the Scores of the Average Pretest and Posttest in Science Process Skills of Grade V Students of SDN 106205 Pasar Baru that were taught by Guided Inquiry and Conventional Learning Models on Water Cycle materials.

Furthermore, the percentage of indicators of science process skills taught by guided inquiry and conventional learning models (Fig. 2). 


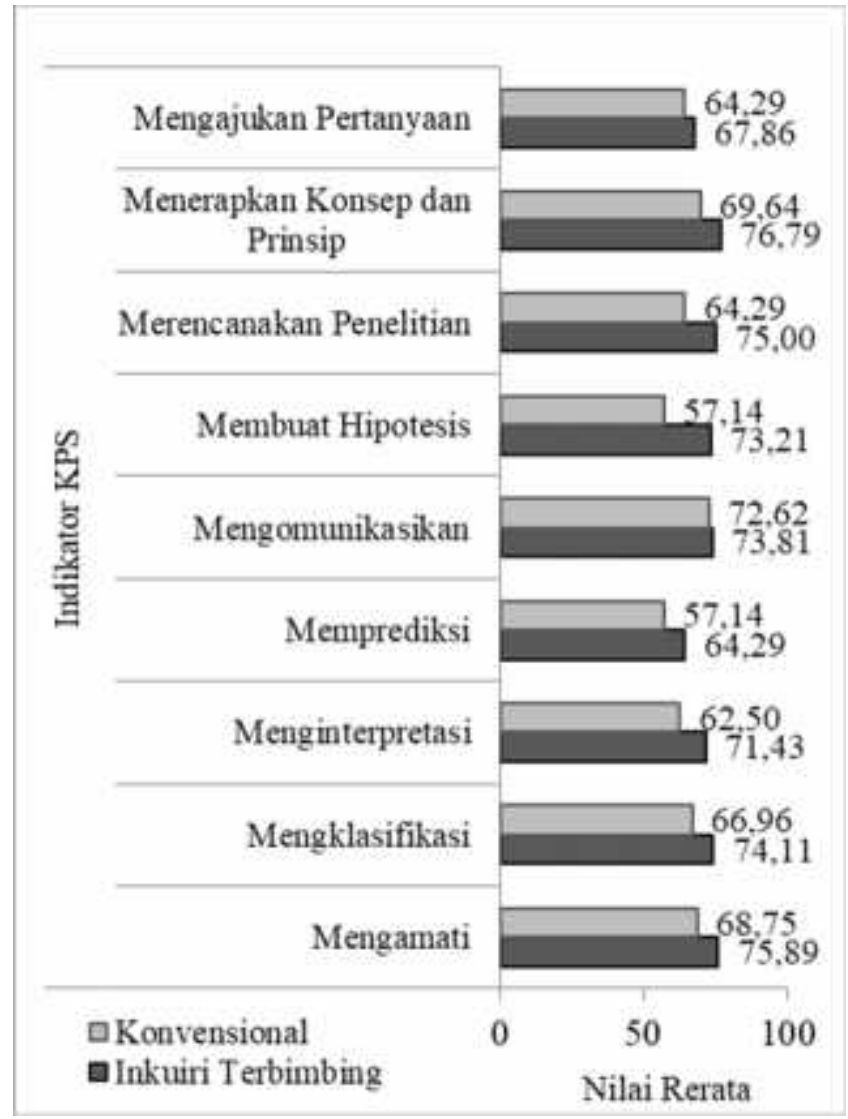

Fig. 2. Percentage of KPS Indicators of Class V Students of SDN 106205 Pasar Baru which are taught by Guided Inquiry and Conventional Learning Models on Water Cycle materials

\section{B. Effect of Learning Model on Cognitive Ability}

The results of the t-test show that the guided inquiry learning model significantly influences students' cognitive abilities. Students 'cognitive abilities taught with guided inquiry are 76.42 significantly higher than students' cognitive abilities taught with conventional learning 65.17 (Fig.3).

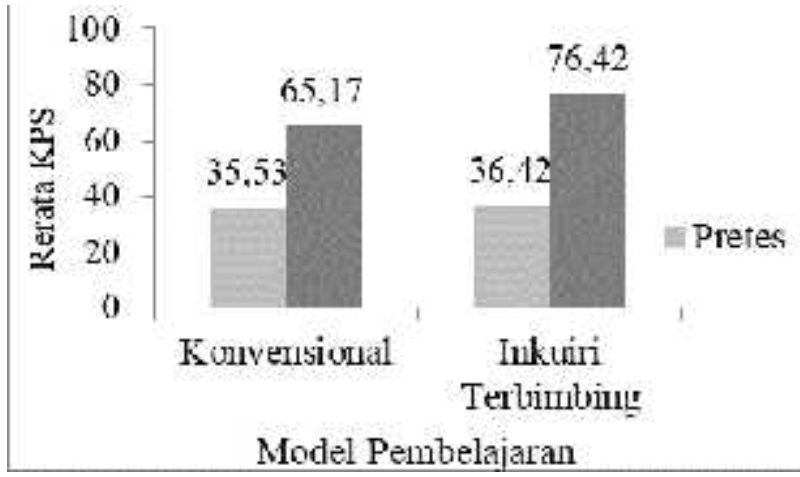

Fig. 3. Differences in Average Pretest and Post-test Scores of Cognitive Ability of Grade V Students of SDN 106205 Pasar Baru which were taught by Guided Inquiry and Conventional Learning Models on Water Cycle materials.

Furthermore, the percentage of indicators of cognitive ability included knowledge (C1), Understanding (C2), Application (C3) and Analysis (C4) which were taught using guided inquiry and conventional learning models (Figure 4).

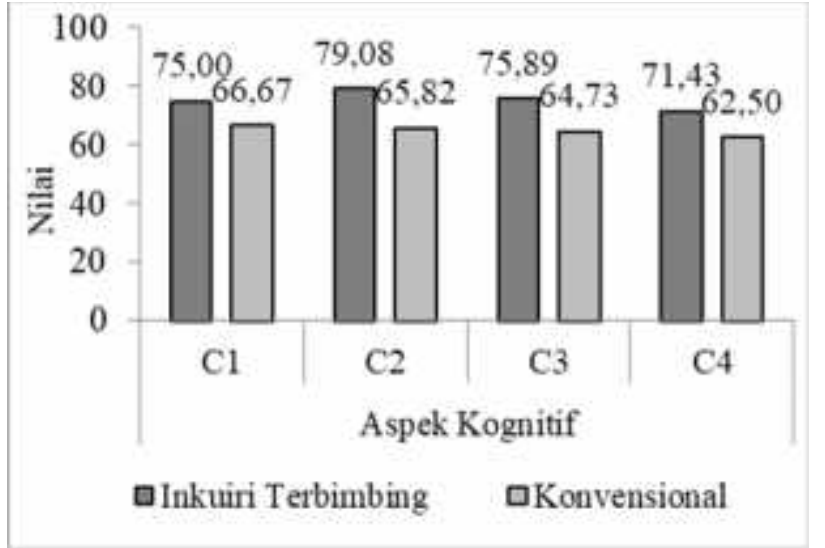

Fig. 4. Percentage of indicators of cognitive ability including knowledge (C1), Comprehension (C2), Application (C3) and Analysis (C4) which are taught with guided inquiry and conventional learning models.

\section{Discussion}

1) Through a Guided Inquiry Learning Model Science Process Skills Students Increase in Making Inventions to Know the Water Cycle: Based on the results of the study show that the average value of science process skills of students taught with guided inquiry learning models is higher (75.71) compared to the average value of students' science process skills taught with conventional learning (64.28). The average posttest of science process skills of students can be seen in Fig. 5.

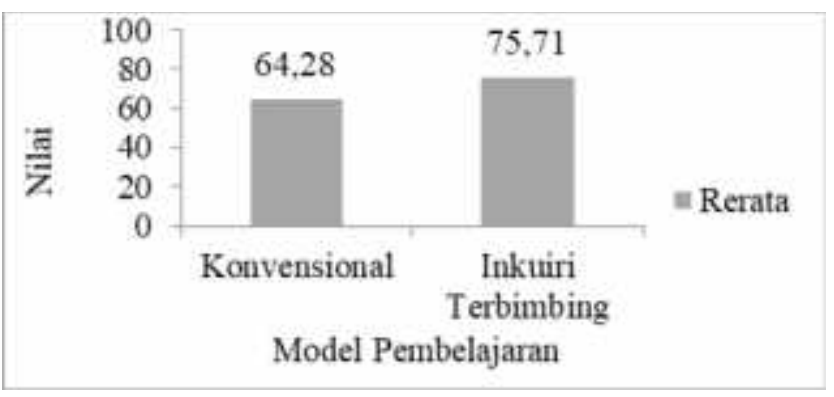

Fig. 5. Mean Value of Posttest Science Process Skills for Class V Students of SDN 106205 Pasar Baru in Water Cycle

Through guided inquiry learning students are able to know the processes of the water cycle through experimental activities. In the experimental activities students can see simple real examples of the processes of the water cycle that occur on earth. With the existence of experimental activities students can use and sharpen science process skills to observe, understand and apply concepts obtained from the learning process in everyday life.

2) Through the Guided Inquiry Learning Model Students' Cognitive Ability Increases in Understanding the Water Cycle: Based on the results of the study, it was obtained that the average cognitive ability of students taught with guided inquiry learning model was 76.42 which was higher than the average cognitive ability of students taught with conventional 
learning, which was 65.17 . The average cognitive ability of students can be seen in Fig. 6.

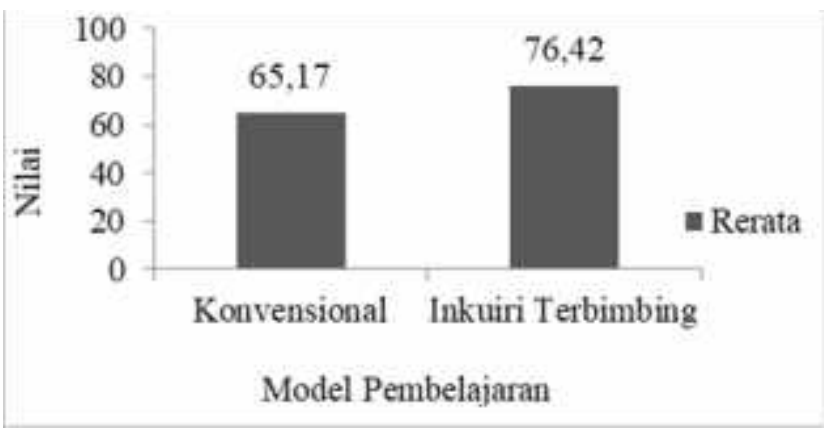

Fig. 6. Average Posttest Value of Cognitive Ability of Class V Students of Pasar Baru Elementary School in Water Cycle material

With guided inquiry learning the cognitive process of students is actively involved in finding information or knowledge because of student-centered learning. Students are able to remember concepts through text that is read and discussions conducted in groups, understand the process of the water cycle through experimental activities regarding the evaporation process, condensation and precipitation. Applying concepts obtained from experimental activities such as the influence of temperature on life on earth and human activities that affect the process of the water cycle. In guided inquiry learning the teacher is only as a facilitator who designs and oversees students carrying out activities in the learning process in the form of interviews, reading and conducting experimental activities

\section{CONCLUSIONS}

The results obtained from this study indicate that there is an influence of guided inquiry learning models and conventional learning models on science process skills and students' cognitive abilities. This also shows that the guided inquiry learning model is effective for improving science process skills and cognitive abilities of students.

\section{References}

[1] Anam, K. 2015. Pembelajaran Berbasis Inkuiri (Metode dan Aplikasi). Yogyakarta: Pustaka Pelajar.

[2] Jauhar, M. 2011. Implementasi PAIKEM dari Behavioristik sampai Konstruktivistik. Jakarta: Prestasi Pustakaraya.

[3] Putra, S. R. 2013. Desain Belajar Mengajar Kreatif Berbasis SAINS. Yogyakarta: DIVA Press.

[4] Rustaman. N. 2005. Strategi Belajar Mengajar Biologi. Malang: Penerbit Universitas Negeri Malang.

[5] Sanjaya, W. 2014. Strategi Pembelajaran Berorientasi Standar Proses Pendidikan. Jakarta: Kencana Prenada Media Group.

[6] Setyanto, A. 2013. Panduan Sukses Komunikasi Belajar Mengajar Jogjakarta: Diva Press

[7] Susanto, A. 2014. Teori Belajar dan Pembelajaran di Sekolah Dasar. Jakarta: Kencana 